\title{
The Effect of Relationship Marketing on Customer Retention in the Jordanian's Pharmaceutical Sector
}

\author{
Abdallah Q. Bataineh ${ }^{1}$, Ghaith M. Al-Abdallah ${ }^{1}$, Hanadi A. Salhab ${ }^{2}$ \& Amer M. Shoter ${ }^{3}$ \\ ${ }^{1}$ Department of Marketing, Faculty of Economics and Administrative Sciences, Applied Science University, \\ Jordan \\ ${ }^{2}$ Department of Marketing, Faculty of Economics and Administrative Sciences, Tabook University, Saudi \\ Arabia \\ ${ }^{3}$ Noorsat Company, Business Development Director, Jordan \\ Correspondence: Abdallah Q. Bataineh, Department of Marketing, Faculty of Economics and Administrative \\ Sciences, Applied Science University, Amman, Jordan. E-mail: a_bataineh@asu.edu.jo
}

Received: January 13, 2015

doi:10.5539/ijbm.v10n3p117
Accepted: February 2, $2015 \quad$ Online Published: February 27, 2015

URL: http://dx.doi.org/10.5539/ijbm.v10n3p117

\begin{abstract}
The major aim of this study is to analyze the effect of relationship marketing factors on customer retention through relationship quality in the Jordanian's pharmaceutical business sector. This study adopted the customers' view; the retail pharmacists who are dealing directly with the pharmaceutical companies' suppliers. The theoretical framework of this study has been tested using data gathered from the questionnaires directed to a total sample of 500 retail pharmacies located in Amman and Zarqa. The statistical results indicated that communication significantly and negatively affects relationship quality. While seller expertise, which is the most influential factor within relationship marketing factors that affects relationship quality, has a significant and positive effect on relationship quality. The results of the comparison level of alternatives showed that it has a positive and significant effect on trust, no effect on satisfaction and positive but insignificant effect on commitment, while the dependence on seller indicated a positive but insignificant effect on commitment and satisfaction, while it has a significant and positive effect on trust. Regarding the results of cooperation, it affects trust and commitment significantly and negatively while it has insignificant and negative effect on satisfaction. The results of the effect of relationship quality on customer retention, showed a significant and positive effect of satisfaction and commitment on customer retention, while trust has insignificant effect on customer retention. Accordingly, research marketing implications, recommendations, and advices for upcoming research are also discussed.
\end{abstract}

Keywords: relationship marketing, relationship quality, customer retention, pharmaceutical sector, Jordan

\section{Introduction}

Retaining customers is an important goal for many business firms in today's extremely competitive market environment, as many competing business firms are spending massive time and money on developing long-term, cooperative relationships with their targeted segments; to facilitate achieving a superior performance in the market place. The progression of relationship marketing concepts has been one of the most essential cornerstones for Business-to-Business (B2B) marketing activities, to ensure sustainable business growth. The importance of relationship marketing has aroused from focusing on the customer lifetime value (CLV), and not the value of only a single transaction. As many marketing researchers considered relationship marketing as the most prominent and flourishing business ever (Juscius \& Grigaite, 2010). In general, the concept of relationship marketing concerns about finding, developing and maintaining customer relationships through establishing long-term successful relationships. Therefore, to increase mutual value and reducing costs; it requires to engage more in supportive and collaborative programs and activities with customers (Sheth and Parvatiyar, 2000). According to Lin and Wu (2011) the main concern in relationship marketing was the impact of relationship quality on customer's retention; they found a significant impact of customer's satisfaction, trust and commitment on retaining customers and increasing the opportunity of more product usage in the future.

In addition to relationship marketing, relationship quality (RQ) has been mentioned by many authors and researcher as an important central construct of relationship marketing as it can improve or destroy the relationship 
between buyers and sellers. For example, (Smith, 1998, p. 78) defined RQ as a general evaluation of the relationship strength, and the degree to which it meet up the expectations and needs of both buyers and sellers depending on history and certain successful or unsuccessful events. However, one of the most vital business sectors in Jordan that are growing at a healthy pace; is the local and multinational pharmaceutical companies, and there is a fierce competition between these pharmaceutical companies' distributors and wholesalers (suppliers), in marketing and selling their products to their customers which are the retail pharmacies. Therefore, the main challenge is how to market their products and prevent their customers (the retail pharmacies) from switching to another distributer or wholesaler (supplier). Thus, pharmaceutical marketing managers are in need for new trends in their marketing activities to be applied by their wholesalers and distributors, to differentiate themselves from other competitors who offer similar products.

\section{Conceptual Framework and Hypothesis Development}

\subsection{Customer Retention}

Maintaining customers has become a key purpose for many organizations; customer retention can generate win win situation for both the firms and the customers, throughout offering economic, social and psychological transactions for customers (Gwinner et al., 1998). Accordingly, the formulation and execution of relationship marketing as strategy to retain customers can provide firms with strong and long term competitive advantage (Roberts et al., 2003). The most important aspect of relationship marketing studies has been the new central role given to the concept of customer retention (Diller, 2000). Relationship marketing can be defined as "the maintenance of the most profitable customers throughout continuing mutual and partnering actions...." (Sheth, 1996, p. 2). On the other hand, the strong emphasis on customer retention; is due to the increased competition between local, international and global markets and assuming that customers' retention will definitely achieve cost efficiency (Reichheld \& Sasser, 1990). Hence, strengthening long-term bonds between customers and suppliers might be affected throughout different variables like trust, commitment, dependence, and cooperation via information exchange (Johnson et al., 1999, p. 12). Finally, firms' progress and growth will heavily depends on firms' capability to identify different types of customers and treat each one of them as separate market and precious asset (Pfeifer et al., 2005, p. 11). According to Reichheld and Sasser, (1990) increasing customers retention by 5 percent will boost profits by 75 percent, and they called it as net present value.

\subsection{Relationship Marketing}

In the past two decades, marketers have shifted their thinking about transactional marketing; as many researchers have indicated a shift from transaction to relationship marketing (Dash et al., 2009). In addition to many researches that have changed their focus from attracting short-term customers; to build long-lasting close customer relationships as (Berry, 1995; Berry \& Parasuraman, 1991; Gronroos, 1994). The concept of relationship marketing reflects deep philosophical culture, which presents the relationship between buyers and sellers as strategic vision (Sin et al. 2005, p.186). Consequently, relationship marketing can be defined as the overall marketing activities aimed at building, enhancing and retaining successful relational exchanges with all stakeholders (Morgan and Hunt, 1994). According to Gummesson (1999) marketing can be described as expandable networks relationships and company-customers based interactions. The factors of relationship marketing were varying between researchers according to the context of the relationship i.e. business-to-business or business-to-customer. Hence, the following factors will be addressed in this research based on the context of B2B marketing.

\subsubsection{Communication}

Several studies have mentioned that the exchange of information between buyers and sellers is an important element of relationship marketing. Communication includes the accuracy, timeliness, adequacy, and credibility of information exchanged (MacNeil, 1980). As a result, superior communications through the supplier organization might create trust among exchange partners. Hence, communication should be considered in terms of frequency, quality, and timely and reliable information exchange. Communication is considered as a significant factor in developing trust in the buyer-seller relationships. Efficient communications may improve synchronization, satisfaction, levels of commitment and performance between channel members (Goodman \& Dion, 2001).

\subsubsection{Seller Expertise}

Seller expertise can reflect the skills and competencies of the service provider as mentioned by (Crosby et al., 1990). Thus, seller expertise is able to assist in reducing customers' potential risks, suspicions and the consequential mind-set of susceptibility that they are probably can experience at some points in the purchasing 
process (Andaleeb \& Anwar, 1996). Professional knowledge, skills and expertise of seller could be the most significant basis for customers' to choose between sellers. Trust and satisfaction of customers towards specific service provider can be increased if the expertise is actually established following consumption (Smith, 1998).

\subsubsection{The Comparison Level of the Alternatives}

The comparison level of alternatives was defined by Anderson \& Narus (1990) as the outcome quality available from the best on hand relationship partner. They found that outcome quality can be resulted from comparing alternatives with each others to determine the dependence degree on each partner. In view of that, low alternative pleasant appearance might lead to customer's retention (Tahtinen \& Vaaland, 2006). Customers' intention to resupport certain suppliers will hinge on substitutability of the current one (Lee \& Cunningham, 2001). As a result, if service providers offer customers with similar quality; then the recognition of high obstacles to way out is emphasized (Colgate \& Norris, 2001). A study by Mummulaneni \& Wilson (1991) has confirmed that the comparison level of the alternatives had negative effect on buyers' commitment to the relationship.

\subsubsection{Cooperation}

According to Anderson \& Narus (1990) cooperation can be defined as alike or complementary coordinated procedures carried out by firms through mutually dependent relationships to accomplish shared outcomes with expected partners over time. Hence, the presence of commitment and cooperation together; can be resulted in helpful actions that allow the partners to receive the relationship benefits. Earlier research on marketing channel has proposed strong relationship between customers' satisfaction and cooperation (Anderson \& Narus 1990; Skinner et al., 1992). The mutual collaboration, joint effort and team spirit, is considered the soul of cooperation concept (Frazier, 1983). In addition, the presence of supportive and cooperative setting between buyers and sellers showed constructive influence on satisfaction, throughout cutting down the unenthusiastic feelings and highlighting encouraging outcomes (Dwyer, 1980; Michie \& Silbey, 1985).

\subsubsection{Dependence on Seller}

The control of the buyer or seller is linked with the interdependence degree on each other in their relationship (Ganesan, 1994). Previous studies on dependence were largely paying attention of the relationships between buyers and sellers in the marketing channel, or between a producer and intermediary (Ganesan, 1994). Accordingly, buyer's dependence can be defined as the degree to which that buyer needs a particular supplier to attain specific goals (Frazier, 1983; Kumar et al., 1995). If the needed product is not available somewhere else, and if a specific goal can only be recognized from a particular relationship; then dependence will be higher (Andaleeb, 1996). In such cases, there are no options for the firms except to maintain their relationship with the current supplier (Frazier, 1983). Since the needed outcomes are extremely appreciated, and the significance of the exchange give the impression of being high; then customer dependence on specific supplier will be also high.

\subsection{Relationship Quality}

Relationship quality focuses on the overall nature of the relationship between the consumer and the firm, and views satisfying consumers' needs as central to relationship success (Hennig-Thurau et al., 2002). Relationship quality defined by Roberts et al., (2003, p.191) as "a measure of the extent to which consumers want to maintain relationships with their service providers". From customers' perspective, relationship quality can be attained throughout sellers' capability to decrease the overall risks perceived by the customers, and offer elevatedrelationship quality. From sellers' perspective, the advantages of relationship quality stem from; decrease marketing costs and enhance profitability, since committed and satisfied customers typically would pay more and they are less sensitive for price fluctuations. Moreover, committed customers will have no attitudes to switch to other suppliers (Reichheld \& Sasser, 1990). In this study, the researchers adopted the comprehensive approach presented by (Hennig-Thurau et al., 2002) and (Roberts et al., 2003) for relationship quality, regarding relationship quality as a meta-construct composed of three interrelated constructs (satisfaction, trust, and commitment).

\subsubsection{Trust}

Buyer confidence in firms competencies consider as good indicator of the healthy relationships between each party, since uncertainty and risks will be disappeared (Sharma \& Patterson, 1999). A reliable relationship is of a vital for both buyer and seller; because it can keep the current bond rather than start looking for new one in which uncertainty will clearly appear (Ramsey \& Sohi, 1997; Lagace et al., 1991). Moreover, trust is a key for improving coordination between buyers and sellers, for the reason that it builds confidence to reach joint goals between them (Morgan \& Hunt, 1994). Hence, a trustworthy relationship resolves disagreements, decrease frustration and put off aggressive attitudes and behaviors, thus lowering conflict from coming out (Anderson 
\&Narus, 1990). The crucial implication and meaning of trust is varying from product-based trust and personbased trust. Thus, partner's capability to grant optimistic outcomes for each other's will draw the commitment levels for the relationship (Rackham \& De Vincentis, 1999). Accordingly, we can hypothesize that:

H01: There is no significant effect of relationship marketing variables (communication, expertise of the seller, comparison level of alternatives, cooperation, and the dependence on the seller) on trust.

\subsubsection{Commitment}

According to the "Investment Model" suggested by Rusbult (1983) commitment was defined as the propensity to continue a relationship and to be expressively and psychologically attracted to it. Based on that, commitment includes two dimensions: (1) psychological attachment and (2) behavioral intentions. The behavioral dimension is noticeable in the Investment Model like the stay/leave decision. The meaning of the commitment construct has been widely acknowledged in the relationship marketing literatures. For instance, in a service marketing context, (Berry \& Parasuraman, 1991, p. 139) state that "relationships are built on the foundation of mutual commitment." Committed relationship partners are unlikely to switch even if a competing supplier performs the same value offer. Accordingly, we can hypothesize that:

H02: There is no significant effect of relationship marketing variables (communication, expertise of the seller, comparison level of alternatives, cooperation, and the dependence on the seller) on commitment.

\subsubsection{Satisfaction}

The concept of customer satisfaction for many decades was found as a central topic; especially in the field of consumer behavior studies. Customer satisfaction has been defined in the context of a relationship marketing as "customers' cognitive and affective evaluation based on their personal experience across all service episodes within the relationship" (Davis-Sramek et al., 2009). Although the clear absence of a practical link between satisfaction and behavioral loyalty; numerous studies showed that satisfaction impact customer retention (Bolton 1998; Bolton, Kannan, \& Bramlett 2000). The fundamental motive is that; customers' aspire to make the most of their utility they could acquire from a particular firm or supplier (Oliver \&Winer 1987); depending on the customer's satisfaction level more satisfied customers are more likely to remain customers. The key to organizational survival and prosperity is the retention of satisfied customers (Fecikova, 2004). Accordingly, we can hypothesize that:

H03: There is no significant effect of relationship marketing variables (communication, expertise of the seller, comparison level of alternatives, cooperation, and the dependence on the seller) on satisfaction.

Although there are some inconsistencies in the literatures on how relationship quality variables affect customer retention, the general agreement exhibits on the importance of them in predicting customer's behavioral intention. In this study, the mediation effect of relationship quality between the independent and dependent variables will be examined. Accordingly, we can hypothesize that:

H04: There is no significant effect of relationship quality constructs (trust, commitment, and satisfaction) as a mediating variable on customer retention.

\section{Research Model}

Based on a thorough analysis of the literature review, the researchers proposed this model, which includes three interrelated parts that are: relationship marketing factors, relationship quality constructs, and customer retention. 


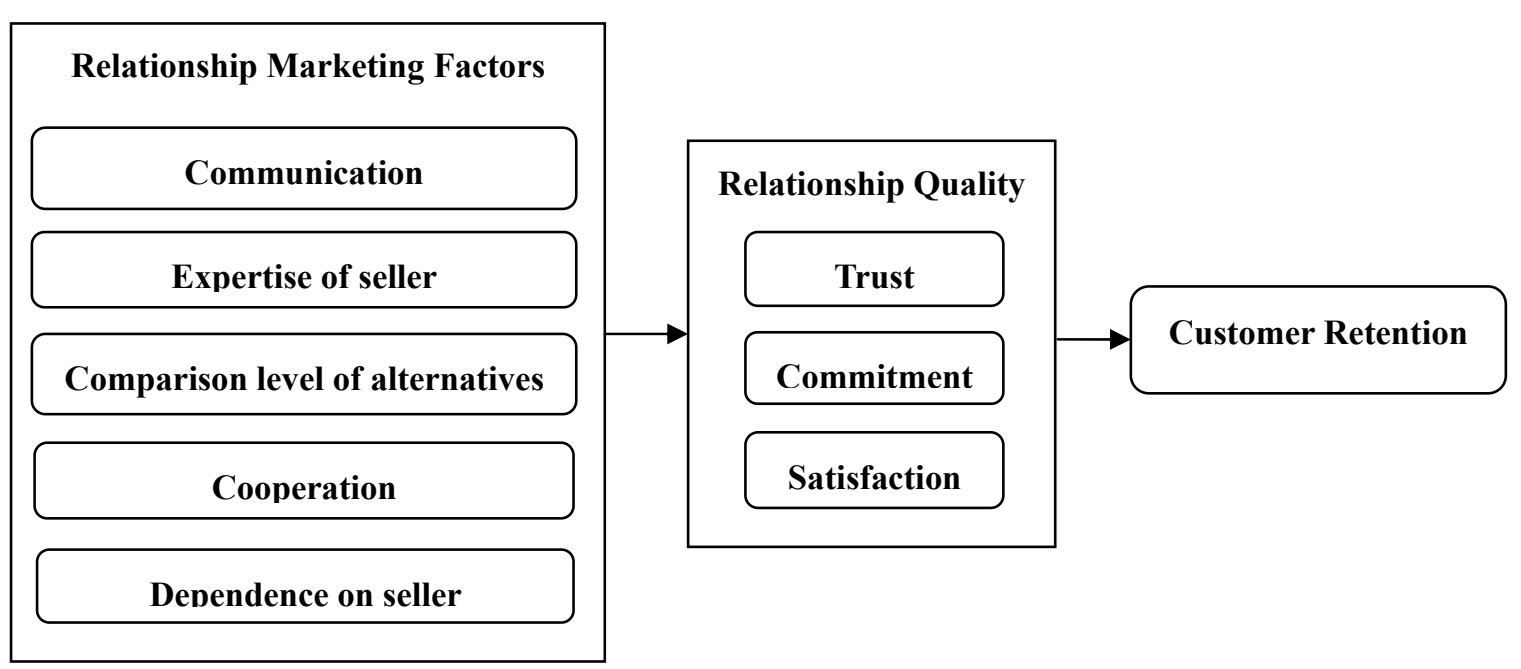

Figure 1. The research model

\section{Research Methodology}

\subsection{Research Population and Sample}

The study population is defined as all retail pharmacies located in Amman and Zarqa as representing provinces dealing with pharmaceutical companies wholesalers and distributers (suppliers). According to recent statistics revealed by Jordanian Pharmaceutical Association 2014, there are (1223) retail pharmacies located in Amman and (318) retail pharmacies located in Zarqa. Accordingly, the overall sample represents 500 authorized pharmacists working at retail pharmacies distributed among Amman and Zarqa, therefore a convenience sample was chosen from greater Amman area and Zarqa, which are considered as a cluster sample due to its diversity. The sample size was determined as follows:

- A convenience sample of 500 authorized pharmacists were set, then questionnaires were distributed to different pharmacies at Amman and Zarqa, the response rate were $92.6 \%$ which is equivalent to 463 .

- Amman area pharmacies represented $74 \%$ of the total sample (500 pharmacists), which is equivalent to 370 pharmacy distributed at different regions in Amman.

- Zarqa area pharmacies represented $26 \%$ of the total sample (500 pharmacists), which is equivalent to 130 pharmacy distributed at different regions in Zarqa.

- The valid number of questionnaires used was (352) from the returned questionnaires from Amman area representing $76 \%$ of the returned questionnaires, while the valid number of questionnaires returned from Zarqa area was (111) representing $24 \%$.

\subsection{Questionnaire and Data Collection}

The research questionnaire has been designed and developed depending on thorough review of relationship marketing and relationship quality literatures. To achieve the research purposes, the measurements of the research variables were adapted from previous studies as demonstrated in table 1.

The study questionnaire consists of the following key four parts:

- Part one related to demographic characteristics of the respondents.

- Part two related to measure relationship marketing factors (communication, seller expertise, comparison level of alternatives, cooperation and dependence) as independent variable.

- Part three related to measure relationship quality constructs (trust, satisfaction and commitment).

- Part four related to measure customer retention as dependent variable by using five-point Likert scale. 
Table 1. Sources of measurement items

\begin{tabular}{cc}
\hline Variable measurement & Reference \\
\hline Relationship marketing factors & \\
Communication with supplier & (Jena, Guin and Dash, 2011) \\
Seller Expertise & (Qin ,Zhao and Xu Yi, 2009) \\
Buyer's Dependence on Supplier & (Jena, Guin and Dash, 2011) \\
Comparison level of alternatives & (Jena, Guin and Dash, 2011) \\
Cooperation & (Juščius and Grigaite,2011) \\
Relationship quality constructs & \\
Trust & (Juščius and Grigaite, 2011) \\
Commitment & (Beatson, Lings and Gudergan, 2008) \\
Satisfaction & (Leonidou, Palihawadana and Theodosiou, 2006) \\
Customer retention & (Jena, Guin and Dash, 2011)
\end{tabular}

\subsection{Research validity and reliability}

This study used two types of validity that are face and content validity. For the face validity, it was assessed through presenting the study instrument to ten academics in the marketing field from reputable universities in Jordan, as well as pharmacists from the Jordanian pharmaceutical sector. They were asked to verify the suitability of the questionnaire to achieve the research objectives, and whether its contents can be understood by the respondents as they are from different sector; providing evidence of face validity, whereas the content validity was assessed through examining and reviewing most of the previous empirical and theoretical literature in the field of relationship marketing, relationship quality and customer retention. Moreover, in order to test the instrument of this research; the researchers conducted a pilot study previous to starting the fieldwork. For the research reliability, it was assessed by examining the Cronbach's Alpha Coefficient. Table 2 below shows that all variables were above the cutoff point which is 0.60 ; and ranged from 0.7119 to 0.9026 . Thus, the internal consistency of the measures used in the research can be considered to be good.

Table 2.Reliability coefficients (Cronbach's Alpha)

\begin{tabular}{cccc}
\hline & Variable & Number of items & Reliability coefficients \\
\hline Independent variables & Communication & 5 & 0.8760 \\
& Expertise of seller & 5 & 0.7717 \\
& Dependence on seller & 7 & 0.8035 \\
& Comparison level of alternatives & 6 & 0.7234 \\
& Cooperation & 5 & 0.7150 \\
Relationship quality & Over all.... & 28 & 0.8542 \\
& Trust & 5 & 0.7517 \\
& Commitment & 4 & 0.7119 \\
& Satisfaction & 3 & 0.7909 \\
Dependent variable & Over all relationship quality & 12 & 0.9026 \\
\hline
\end{tabular}




\section{Data Analysis and Findings}

\subsection{Sample Characteristics}

Table 3.Distribution of the sample based on demographical variables

\begin{tabular}{|c|c|c|c|}
\hline Characteristics & & Frequency & Percentage \% \\
\hline \multirow{2}{*}{ Gender } & Male & 158 & 34.1 \\
\hline & Female & 305 & 65.9 \\
\hline \multirow{5}{*}{ Age } & $24-30$ & 74 & 16.0 \\
\hline & $31-37$ & 126 & 27.2 \\
\hline & $38-44$ & 115 & 24.8 \\
\hline & $45-51$ & 74 & 16.0 \\
\hline & OVER 52 & 74 & 16.0 \\
\hline \multirow{3}{*}{ Education level } & College Community & 74 & 16.0 \\
\hline & BA & 315 & 68.0 \\
\hline & MA & 74 & 16.0 \\
\hline \multirow{3}{*}{ Occupation } & Pharmacy Manager & 116 & 25.1 \\
\hline & Responsible Pharmacist & 310 & 67.0 \\
\hline & Owner Pharmacist & 37 & 8.0 \\
\hline \multirow{3}{*}{ Income } & $400-699$ & 199 & 43.0 \\
\hline & $700-999$ & 190 & 41.0 \\
\hline & More Than 1000 & 74 & 16.0 \\
\hline \multirow{4}{*}{ Years of Experience } & Less than 5 & 84 & 18.1 \\
\hline & $6-10$ & 79 & 17.1 \\
\hline & $11-15$ & 115 & 24.8 \\
\hline & OVER than 15 & 185 & 40.0 \\
\hline \multirow{2}{*}{$\begin{array}{l}\text { Average } \\
\text { Worked/Day }\end{array}$} & Less than 8 & 352 & 76.0 \\
\hline & $9-12$ & 111 & 24.0 \\
\hline \multirow{2}{*}{ Pharmacy Type } & Chain Pharmacy & 42 & 9.1 \\
\hline & Independent Pharmacy & 421 & 90.9 \\
\hline \multirow{2}{*}{ Location } & Amman & 352 & 76.0 \\
\hline & Zarqa & 111 & 24.0 \\
\hline
\end{tabular}

Table 3 shows descriptive statistical analysis has been used to describe the sample demographic characteristics. The results showed that the highest percentage of the respondents were females representing $(65.9 \%)$ of total sample while the males were only (34.1\%), this result indicates that females are occupying this type of job more than males do. Regarding the highest percentage of the respondents' age, the findings showed that (27.2\%) representing the category of (31-37 years) followed by the category of (38-44 years) representing (24.8\%) of the respondents. This result indicates that most of the respondents occupying the authorized pharmacist job; are from middle age categories which is logical as this age category has enough experience to be an authorized pharmacist. In addition that most of the young freshly graduated pharmacists prefers to occupy other type of job as to work as medical representatives at different pharmaceutical companies. The majority of the respondents' education level was bachelor representing $(68 \%)$ of the sample, this is a logical result as working in this position does not need a higher educational degree. Regarding the highest percentage of the respondents' occupation was as responsible pharmacists representing (67\%) of the sample followed by pharmacy managers representing $(25.1 \%)$ of the sample. This result indicates that mostly the responsible pharmacist is authorized to deal with the pharmaceutical companies suppliers. The highest percentage of the respondents' income was the category from (400-699JD), which represent (43\%) of the sample, followed by the category (700-999JD) representing (41\%) of the sample. A percentage of $(40 \%)$ about the respondents years of experience was of those years of experience is over 15 years, then around (24.8\%) of the respondents' years of experience range from (11-15 years), while (18.1\%) of the respondents' years of experience were less than 5 years. Regarding the average hours worked per day $(76 \%)$ of the respondent work less than eight hours per day. The results in the table showed that the highest percentage of retail pharmacies type was independent pharmacies representing (90.9\%) of the sample, and only $(9.1 \%)$ were of chain pharmacies type. This result is logical as the dominating type of pharmacies is the independent pharmacies while the chain pharmacies are few as it is a new trend in Jordan. The highest percentage of retail pharmacies was located 
in Amman representing (76\%) of the sample, while (24\%) of the retail pharmacies were located in Zarqa.

\subsection{Hypothesis Testing}

With the purpose of testing the research hypotheses, multiple regression analyses model were run to examine the relationships between the research variables.

H01: There is no significant effect of relationship marketing (communication, seller expertise, comparison level of alternatives, cooperation and the dependence on the seller) on trust.

A multiple regression test has been used to determine the effect of the independent variable relationship marketing including (communication, seller expertise, comparison level of alternatives, cooperation and the dependence on the seller) on trust. The table (4) below shows the results:

Table 4. Results of multiple regressions for H01

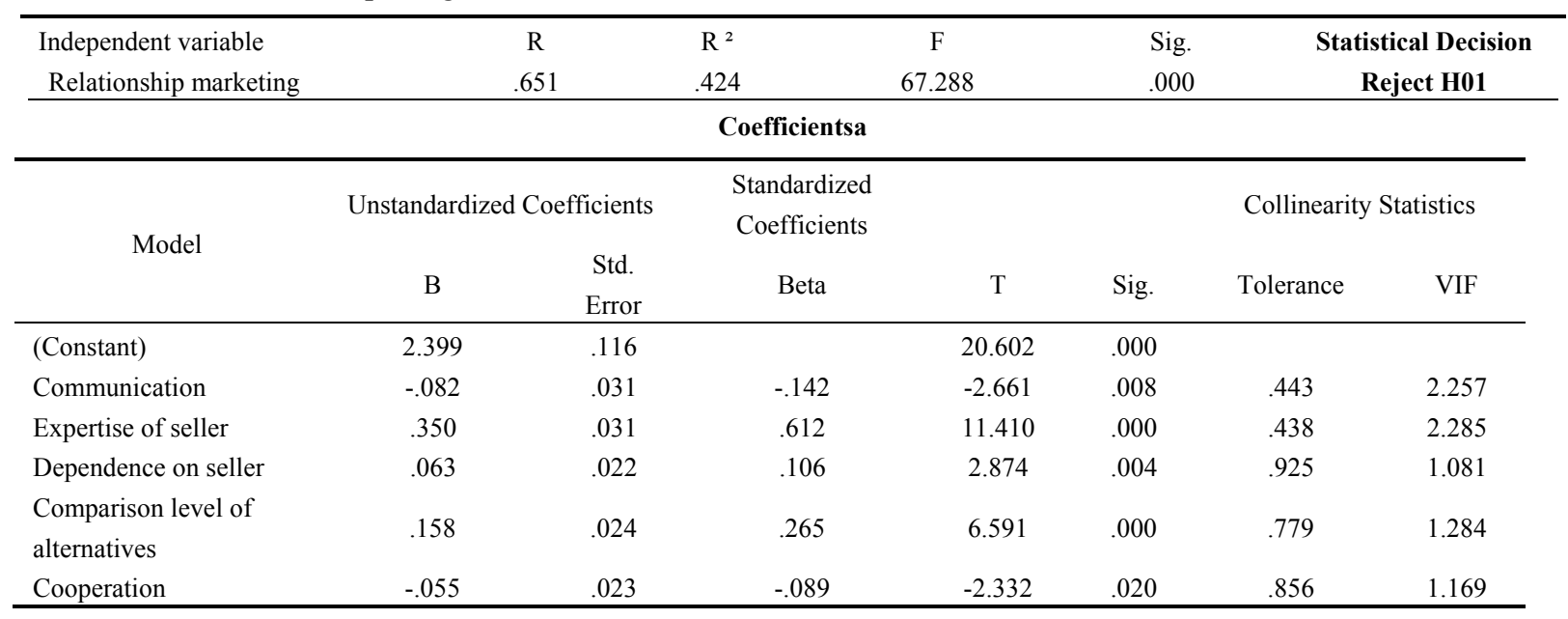

The findings of $\mathrm{H} 01$ indicated that the multicollinearity problem were not found, since the tolerance value of all variables were found more than 0.40 and the variance inflation factor (VIF) is less than ten (Hair et al., 1998). In addition, the model has met the required assumptions to make sure of the significance and validity of this test (Ooi et al., 2006). The results in the table indicate that relationship marketing factors (communication, seller expertise, comparison level of alternatives, cooperation and the dependence on the seller) have a statistical significant effect on trust. By using significance level of $(\alpha \leq 0.05)$ the H01 is rejected and Hal is accepted as the obtained p-value which was (0.000) that is less than (0.05); indicating that relationship marketing factors has statistically significant effect on trust as one of RQ constructs. Furthermore, the value of $\left(\mathrm{R}^{2}\right)$ was $(0.424)$, representing that $(42.4 \%)$ of the variance of the dependent variable (trust) can be noticeably interpreted through all independent variables. Therefore, there is an effect of the relationship marketing factors on trust. Accordingly, communication and cooperation significantly and negatively affects trust, as the communication $\beta$ - value is $(-.142)$ and the $t-$ value is $(-2.661)$, while cooperation $\beta$ - value is (-.089) and the t- value is (-2.332). Seller Expertise significantly and positively affects trust, as its $\beta$-value is $(0.612)$ and the t- value is $(11.410)$. Dependence on seller significantly and positively affects trust, as its $\beta$-value is (0.106) and the t- value is (2.874). The comparison level of alternatives has a significant and positive effect on trust as its $\beta$ - value is (0.265) and the t- value is (6.591). Seller Expertise is the most influential variable within relationship marketing variables that explains the variation in the dependent variable (trust), followed by the Comparison level of alternatives.

H02: There is no significant effect of relationship marketing (communication, seller expertise, comparison level of alternatives, cooperation and the dependence on the seller) on commitment.

A multiple regression test has been used to determine the effect of the independent variable relationship marketing including (communication, seller expertise, comparison level of alternatives, cooperation and the dependence on the seller) on commitment. The table 5 below shows the results: 
Table 5. Results of multiple regression for $\mathrm{H} 02$

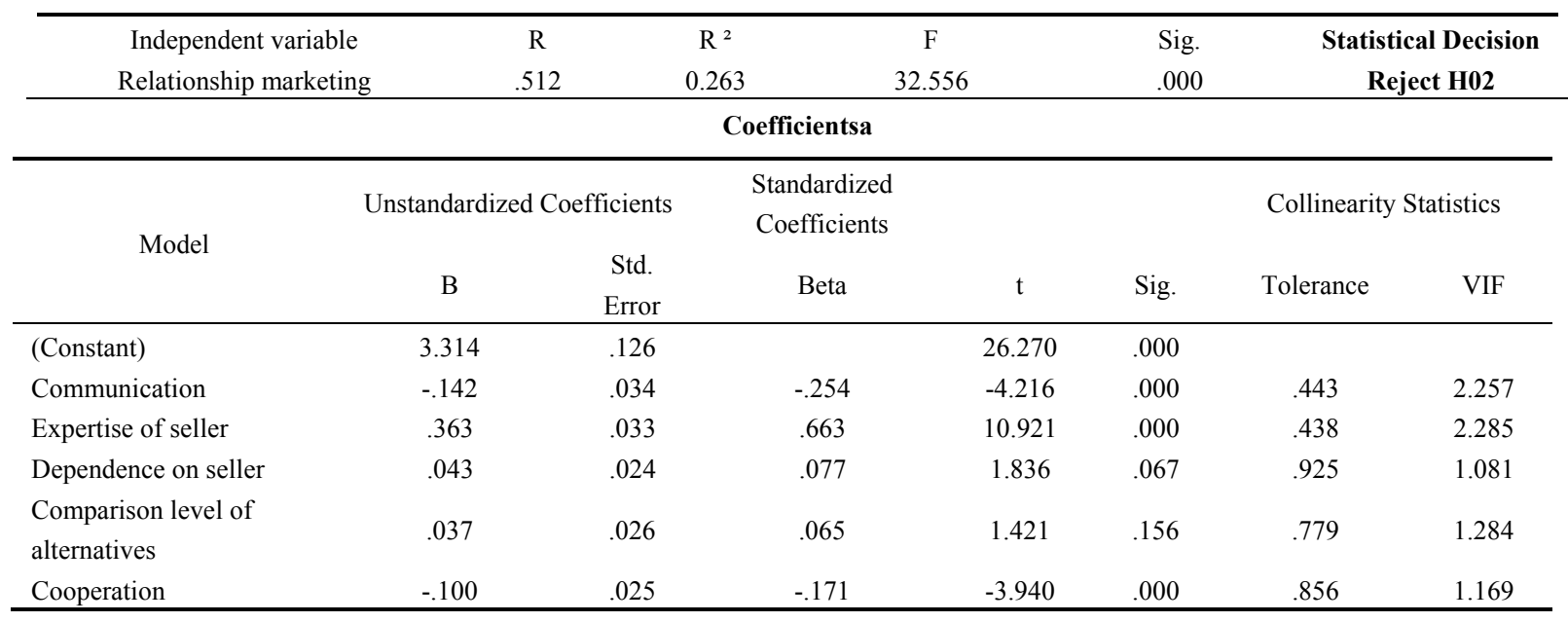

The findings of $\mathrm{H} 02$ indicated that the multicollinearity problem were not found, since the tolerance value of all variables were found more than 0.40 and the variance inflation factor (VIF) is less than ten (Hair et al., 1998). In addition, the model has met the required assumptions to make sure of the significance and validity of this test (Ooi et al., 2006). The results in table 5 indicate that relationship marketing variables (communication, expertise of the seller, cooperation) have a statistical significant effect on commitment. By using significance level of $(\alpha \leq 0.05)$ the $\mathrm{H} 02$ is rejected and Ha2 is accepted, that is based on the p- value obtained which was $(0.000)$ that is less than (0.05). This indicated that the overall model of relationship marketing factors have a statistically significant effect on commitment. Furthermore, the value of $\left(\mathrm{R}^{2}\right)$ was $(0.263)$, representing that $(26.3 \%)$ of the variance of the dependent variable (commitment) can be explained by the three independent variables of relationship marketing (communication, expertise of the seller, cooperation). Thus, three independent variables of relationship marketing (communication, expertise of the seller, cooperation) have an effect on commitment. Accordingly, communication and cooperation negatively and significantly affects commitment, as the communication $\beta$-value is $(-.254)$ and the $\mathrm{t}$ - value is (-4.216), while cooperation $\beta$-value is $(-.171)$ and the t- value is $(-3.940)$. Seller expertise significantly and positively affects commitment, as the seller expertise $\beta$-value is $(0.663)$ and the t-value is (10.921). Seller Expertise is the most influential variable within relationship marketing variables that explains the variation in the dependent variable (commitment). Dependence has a positive but insignificant effect on commitment, as dependence $\beta$-value is (0.077) and the t-value is (1.836). The comparison level of alternatives has a positive but not significant effect on commitment, as its $\beta$ - value is (0.065) and the t-value is (1.421).

H03: There is no significant effect of relationship marketing (communication, seller expertise, comparison level of alternatives, cooperation and the dependence on the seller) on satisfaction.

A multiple regression test has been used to determine the effect of the independent variable relationship marketing including (communication, seller expertise, comparison level of alternatives, cooperation and the dependence on the seller) on satisfaction. The table 6 below shows the results: 
Table 6. Results of multiple regression for $\mathrm{H} 03$

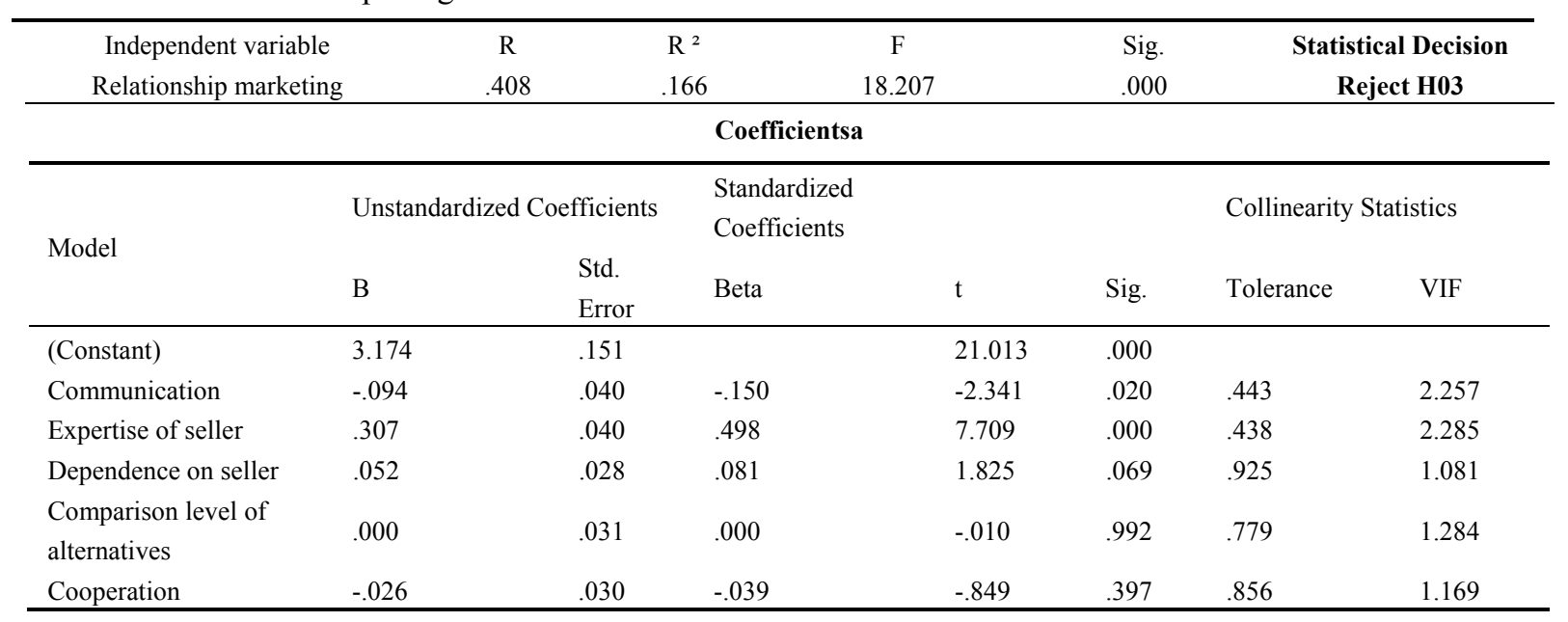

The findings of $\mathrm{H} 03$ indicated that the multicollinearity problem were not found, since the tolerance value of all variables were found more than 0.40 and the variance inflation factor (VIF) is less than ten (Hair et al., 1998). In addition, the model has met the required assumptions to make sure of the significance and validity of this test (Ooi et al., 2006). The results in table 6 indicate that relationship marketing factors (communication and seller expertise) have a statistical significant effect on satisfaction. By using significance level of $(\alpha \leq 0.05)$ the $\mathrm{H} 03$ is rejected and $\mathrm{Ha} 3$ is accepted, that is based on the p- value obtained which was $(0.000)$ that is less than $(0.05)$. This indicates that only two relationship marketing factors (communication and seller expertise) have a statistical significant effect on satisfaction. Furthermore, the value of $\left(\mathrm{R}^{2}\right)$ was $(0.166)$, representing that $(16.6 \%)$ of the variance of the dependent variable satisfaction can be explained by two independent variables of relationship marketing (communication and seller expertise). Thus, there is an effect of the relationship marketing on satisfaction. Accordingly, communication negatively and significantly affects satisfaction, as the communication $\beta$-value is $(-0.150)$ and the $\mathrm{t}$-value is (-2.341). While cooperation has a negative and insignificant effect on satisfaction as its $\beta$-value is $(-0.039)$ and the $t$ - value is $(-0.849)$. Seller expertise has a significant and positive effect on satisfaction as its $\beta$-value is (.498) and the t-value is (7.709). Seller expertise is the most influential variable within relationship marketing factors that explains the variation in the dependent variable (satisfaction). The comparison level of alternatives has no statistical effect on the dependent variable (satisfaction) as its $\beta$-value is $(0.000)$ and the $t$-value is $(-0.10)$. Dependence has a positive but insignificant effect on the dependent variable (satisfaction).

H04: There is no significant effect of relationship quality constructs (trust, commitment and satisfaction) on customer retention.

A multiple regression test has been used to determine the effect of the independent variable relationship quality (trust, commitment and satisfaction) on the dependent variable customer retention. The table 7 below shows the results:

Table 7.Results of multiple regression for $\mathrm{H} 04$

\begin{tabular}{|c|c|c|c|c|c|c|c|}
\hline Independent variable & $\mathrm{R}$ & $\mathrm{R}^{2}$ & $\mathrm{~F}$ & & Sig. & \multirow{2}{*}{\multicolumn{2}{|c|}{$\begin{array}{c}\text { Statistical Decision } \\
\text { Reject H04 }\end{array}$}} \\
\hline Relationship Quality & .903 & .816 & 677.414 & & .000 & & \\
\hline \multicolumn{8}{|c|}{ Coefficientsa } \\
\hline \multirow[t]{2}{*}{ Model } & \multicolumn{2}{|c|}{$\begin{array}{c}\text { Unstandardized } \\
\text { Coefficients }\end{array}$} & \multirow{2}{*}{$\begin{array}{c}\text { Standardized } \\
\text { Coefficients } \\
\text { Beta }\end{array}$} & \multirow[b]{2}{*}{$\mathrm{t}$} & \multirow[b]{2}{*}{ Sig. } & \multicolumn{2}{|c|}{ Collinearity Statistics } \\
\hline & $\mathrm{B}$ & Std. Error & & & & Tolerance & VIF \\
\hline $\begin{array}{l}\text { (Constant) } \\
\text { Relationship quality }\end{array}$ & .475 & .083 & & 5.736 & .000 & & \\
\hline Trust & .021 & .034 & .022 & .613 & .540 & .326 & 3.063 \\
\hline Commitment & .295 & .043 & .291 & 6.922 & .000 & .227 & 4.399 \\
\hline Satisfaction & .567 & .033 & .629 & 16.941 & .000 & .291 & 3.435 \\
\hline
\end{tabular}


The findings of H04 indicated that the multicollinearity problem were not found, since the tolerance value of all variables were found more than 0.20 and the variance inflation factor (VIF) is less than ten (Hair et al., 1998). In addition, the model has met the required assumptions to make sure of the significance and validity of this test (Ooi et al., 2006). Table 7 results indicate that relationship quality (commitment and satisfaction) has an effect on customer retention. By using significance level of $(\alpha \leq 0.05)$ the $\mathrm{H} 04$ is rejected and Ha4 is accepted, that is based on the p-value obtained which was $(0.000)$ that is less than $(0.05)$. Furthermore, the value of $\left(\mathrm{R}^{2}\right)$ was $(0.816)$, representing that $(81.6 \%)$ of the variance of the dependent variable customer retention can be noticeably interpreted through the two independent variables of relationship quality (commitment and satisfaction). Accordingly, relationship quality constructs (commitment and satisfaction) have a positive and significant effect on the dependent variable customer retention. The most influential variable within relationship quality constructs that explains the variation in the dependent variable (customer retention) is satisfaction followed by commitment. Satisfaction has a significant and positive effect on customer retention as its $\beta$-value is $(0.629)$ and the $t$-value is (16.94). Commitment has a significant and positive effect on customer retention as its $\beta$-value is $(0.291)$ and the $\mathrm{t}$-value is (6.922). Trust has positive but insignificant effect on customer retention.

\section{Results Discussion and Conclusion}

The four hypotheses of the study have been analyzed, the results shown that relationship marketing has an effect on relationship quality which leads to customer retention. It has been found from the statistical analysis that relationship marketing has a statistically significant effect on relationship quality. However, there was a varying effect among the relationship marketing factors (communication, seller expertise, comparison level of alternatives, cooperation and dependence) on relationship quality constructs (trust, commitment and satisfaction) as follows: The results of this study indicated that communication as a relationship marketing factor has a reverse or negative effect on RQ; and that consistent with (Goodman \& Dion 2001) study which indicated that effective communication in channel relationships enhances the channel members' coordination, satisfaction, commitment, and performance. Hence, it is concluded from previous studies that communication plays a positive and significant role in improving relationship quality, as communication ensures both parties understanding and sharing information with each other. For seller expertise it has a positive and significant effect on relationship quality constructs (trust, commitment and satisfaction), in addition to that; it is the most influential factor within relationship marketing factors that affects relationship quality constructs and that consistent with (Andaleeb\& Anwar, 1996). Customers' selection of a service provider hinges on seller expertise and professional knowledge, since the expertise is proven; then customers trust and satisfaction towards the service provider will be increased (Smith, 1998). The dependence on seller was positively but insignificantly affects' commitment and satisfaction, and that consistent with (Andaleeb, 1996). In terms of the comparison level of alternatives, results showed that it has a positive and significant effect on trust, no effect on satisfaction and positive but insignificant effect on commitment and that consistent with (Mummulaneni\& Wilson, 1991). While cooperation has a negative but significant effect on trust and commitment, while it has a negative insignificant effect on satisfaction and that consistent with (Anderson \&Narus 1990; Skinner et al. 1992). For the relationship quality constructs (trust, commitment and satisfaction), the result of this study showed a positive and significant effect of satisfaction and commitment on customer retention, and that consistent with (Lin \& Wu, 2011), while trust has no effect on customer retention. The result of this study concerning that relationship quality has a positive and significant effect on customer retention, is in agreement with a previous study made by (Ramsey \&Sohi, 1997) that concluded that customer satisfaction from the service provider leads to positive behavioral outcomes, such as repeated purchase and positive word-of-mouth. Thus, the base for customers' retention was satisfaction. This study indicated that customer trust had insignificant effect on customer retention; this result can be explained as trusting the pharmaceutical supplier was not an indicator for customer retention, which means that there is a problem in trusting the pharmaceutical suppliers as (Rackham \& De Vincentis, 1999) have reported in their research that the role of trust changes from trusting the product/ service in transactional selling to trusting the sales person and trusting supplier firm in strategic selling.

\section{Marketing Implications'}

Based on this research analysis, results and conclusions, there are potential marketing implications that pharmaceutical marketing managers should carefully address while applying relationship marketing through their suppliers:

- Pharmaceutical marketing managers and their suppliers should focus on effective communication programs with their buyers the retail pharmacists. As performing social meeting with key customers to strengthen their relationship bonds and to uncover customers' needs. Thus, the exchange of information is 
an important element of relationship marketing as communication improves relationship quality which leads to customer retention.

- Pharmaceutical marketing managers should focus more on improving their suppliers' skills, abilities and competence; through implementing continues educational programs. As seller specialized knowledge and expertise are the most essential criteria for buyers in the selection of a certain seller which might assist customers to decrease the uncertainties.

- Pharmaceutical marketing managers and their suppliers should differentiate themselves from other alternatives in the marketplace, through offering differentiated and customized services for key customers, and building up bonus programs for special customers in order to overcome other alternative competitors and obtain customers dependence.

- Pharmaceutical marketing managers and their suppliers should be more cooperative internally and with their buyers the retail pharmacists through offering certain facilities and services, as cooperation between the exchange parties leads to mutual and individual goals jointly. Hence, cultivating a cooperative climate has a favorable effect on customer satisfaction, trust and commitment; so the relationship quality will be improved leading to customer retention.

- Pharmaceutical marketing managers and their suppliers should realize that relationship quality is a corner stone in relationship marketing; they should emphasize on improving RQ constructs (trust, commitment and satisfaction) which will affects customer retention.

\section{Recommendations and Future Research}

Pharmaceutical marketing managers should focus on building trust between their suppliers and buyers to reduce uncertainty and risks. Moreover, pharmaceutical marketing managers might focus on gaining buyers commitment and satisfaction through improved relationship quality. Both suppliers and buyers, who are committed to a relationship, will probably intend to keep on in the relationship, and they will strongly have feelings of psychological and emotional attachment to it. Also they can segmenting and targeting the key retail pharmacists; to obtain a data base for the important customer needs and expectations in order to keep in touch with them for building long term relationships, and to build a successful relationship marketing as a strategic tool for retaining customers, and put into practice such a strategy through a high relationship quality will provide firms with a sustainable competitive advantage. And finally, the findings and the boundaries of this study open the door for future research to test the impact of relationship marketing on relationship quality and the effect of the later on customer retention. Future research also may investigate others factors affecting relationship quality and customer retention. This study has tested the effect of relationship marketing on customer retention in Jordan pharmaceutical sector. Upcoming research might want to apply several aspects of these findings in other economical sectors. Besides that, this research has been done on Business to Business sector.

\section{References}

Andaleeb, S. S. (1996). An experimental investigation of satisfaction and commitment in marketing channels: The role of trust and dependence. Journal of Retailing, 72(1), 77-93. http://dx.doi.org/10.1016/S0022-4359

Andaleeb, S., \& Anwar, S. (1996). Factors influencing customer trust in salespersons in a developing country. Journal of International Marketing, 4(4), 35-52.

Anderson, J. C., \& Narus, J. A. (1990). A Model of Distributor Firm and Manufacturer Firm Working Partnerships. Journal of Marketing, 54, 42-58. http://dx.doi.org/10.2307/1252172

Beatson, A., Lings, I., \& Gudergan, S. (2008). Employee behaviour and relationship quality: Impact on customers. The Services Industries Journal, 28(2), 211-223. http://dx.doi.org/10.1080/02642060701842282

Berry, L. L. (1995). Relationship marketing of services growing interest, emerging perspectives. Journal of the Academy of Marketing Science, 23(Fall), 236-45. http://dx.doi.org/10.4135/9781452231310.n6

Berry, L. L., \& Parasuraman, A. (1991). Marketing services: Competing through quality. New York: The Free Press.

Bolton, P. K. K., \& Mathew, D. B. (2000). Implications of Loyalty Program Membership and Service Experiences for Customer Retention and Value. Journal of the Academy of Marketing Science, 28(winter), 95-108. http://dx.doi.org/10.1177/0092070300281009

Bolton, R. N. (1998). A Dynamic Model of the Duration of the Customer's Relationship with a Continuous Service Provider: The Role of Satisfaction. Marketing Science, 17(winter), 45-65. 
Colgate, M., \& Norris, M. (2001).Developing a comprehensive picture of service failure. International Journal of Service Industry Management, 12(3/4), 215-234. http://dx.doi.org/10.1108/09564230110393211

Crosby, L. A., Evans, K. R., \& Cowles, D. (1990). Relationship quality in services selling: An interpersonal influence perspective. Journal of Marketing, 54(3), 68-81. http://dx.doi.org/10.2307/1251817

Dash, S., Brunning, E., \& Guin, K. (2009). A cross-cultural comparison of individualism's moderating effect on bonding and commitment in banking relationships. Marketing Intelligence and Planning, 27(1). http://dx.doi.org/10.1108/02634500910928380

Davis-Sramek, B., Droge, C., Mentzer, J. T., \& Myers, M. B. (2009). Creating commitment and loyalty behavior among retailers: what are the roles of service quality and satisfaction? Journal of Academy of Marketing Science, 37(4), 440-454. http://dx.doi.org/10.1007/s11747-009-0148-y

Diller, H. (2000).Customer Loyalty: Fata Morgana or Realistic Goal? Managing Relationships with Customer.

Dwyer, F. R. (1980). Channel-member satisfaction: laboratory insights. Journal of Retailing, 56(2), 45-65.

Fecikova, I. (2004). An index method of customer satisfaction. TQM Magazine, 16(1), 57-66.

Frazier, G. L. (1983). On the measurement of interfirm power in channels of distribution. Journal of Marketing Research, 20(2), 158-166. http://dx.doi.org/10.2307/3151682

Ganesan, S. (1994). Determinants of long-term orientation in buyer-seller relationships.Journal of Marketing, 58(1), 1-19. http://dx.doi.org/10.2307/1252265

Goodman, L. E., \& Dion, P. A. (2001).The determinants of commitment in the distributor-manufacturer $\begin{array}{llll}\text { relationship. Industrial } & \text { Marketing }\end{array}$ http://dx.doi.org/10.1016/S0019-8501(99)00092-9

Gronroos, C. (1994). From marketing mix to relationship marketing: Towards a paradigm shift in marketing. Management Decision, 32(2), 4-20.

Gummesson, E. (1999). Total Relationship Marketing. Butterworth-Heinemann, Oxford.

Gwinner, K. P., Gremler, D. D., \&Bitner, M. J. (1998). Relational benefits in services industries: The customer's perspective. Journal of the Academy of Marketing Science, 26(2), 101-114. http://dx.doi.org/10.1177/0092070398262002

Hair, J. F. Jr., Anderson, R. E., Tatham, R. L., \& Black, W. C. (1998). Multivariate Data Analysis (5th ed.). Prentice-Hall International, Upper Saddle River, NJ.

Hennig-Thurau, T., Gwinner, K. P., \& Gremler, D. D. (2002).Understanding relationship marketing outcomes: an integration of relational benefits and relationship quality. Journal of Service Research, 4(3), 230-247. http://dx.doi.org/10.1177/1094670502004003006

Jena, S., Guin, K. K., \& Dash, S. B. (2011). Effect of relationship building and constraint-based factors on business buyers' relationship continuity intention: A study on the Indian steel industry. Journal of Indian Business Research, 3(1), 22- 42. http://dx.doi.org/10.1108/17554191111112451

Johnson, W. C., Chinuntdej, N., \& Weinstein, A. (1999).Creating value through customer and supplier relationships. IMP 15th Annual Conference, 1-15.

Juščius, V., \& Grigaite, V. (2011). Relationship marketing practice in Lithuanian logistics organizations. Baltic Journal of Management, 6(1), 71-88.

Juscius, \& Grigaite. (2010). Relationship marketing practice in Lithuanian logistics organizations. Baltic Journal of Management, 6(1).

Kumar, N., Scheer, L. K., \&Steenkamp, J. (1995).The effects of perceived interdependence on dealer attitudes.Journal of Marketing Research, 32(3), 348-356. http://dx.doi.org/10.2307/3151986

Lagace, R., Dahlstrom, R., \&Gassenheimer, J. (1991).The relevance of ethnical salesperson behavior on relationship quality: the pharmaceutical industry. Journal of Personal Selling \& Sales Management, 11(4), 39-47.

Lee, M., \& Cunningham, L. F. (2001).A cost/benefit approach to understanding service loyalty. Journal of Services Marketing, 15(2), 113-130. http://dx.doi.org/10.1108/08876040110387917

Leonidas, C., Leonidou, D. P., \& Marios, T. (2006).An integrated model of the behavioral dimensions of industrial buyer-seller relationships. European Journal of Marketing, 40(1/2), 145-173. 
Lin, J. S. C., \& Wu, C. Y. (2011).The role of expected future use in relationship-based service retention. Managing Service Quality, 21(5), 535-551. http://dx.doi.org/10.1108/09604521111159816

Macneil, I. R. (1980).The New Social Contract: An Enquiry into Modern Contractual Relations. Yale University Press, New Haven, CT.

Michie, D. A., \& Silbey, S. D. (1985). Channel member satisfaction: controversy resolved. Journal of the Academy of Marketing Science, 13(2), 188-205. http://dx.doi.org/10.1007/BF02729714

Morgan, R. M., \& Hunt, S. D. (1994).The commitment-trust theory of relationship marketing.Journal of Marketing, 58(3), 20-38. http://dx.doi.org/10.2307/1252308

Mummalaneni, V., \& Wilson, D. T. (1991).The influence of a close personal relationship between a buyer and a seller on the continued stability of their role relationship. ISBM Report 4-1991, Pennsylvania State University, University Park.

Oliver, R., \& Russel, S. W. (1987).A Framework for the Formation and Structure of Consumer Expectations: Review and Propositions. Journal of Economic Psychology, 8(4), 469-499. http://dx.doi.org/10.1016/0167-4870(87)90037-7

Ooi, K. B., Safa, M. S., \& Arumugam, V. (2006). TQM practices and affective commitment: A case of Malaysian semiconductor packaging organizations. Int. J. Manage. Entrepreneurship, 2(1), 37-55.

Qin, S., Zhao, L., \& Yi, X. (2009). Impacts of customer service on relationship quality: An empirical study in China. Managing Service Quality, 19(4), 391-409.

Rackham, N., \& De, V., John, R. (1999).Rethinking the Sales Force: Redefining Selling to Create and Capture Customer Value. New York: McGraw Hill.

Ramsey, R., \& Sohi, R. (1997). Listening to your customers: the effect of perceived salesperson listening behavior on relationship outcomes. Journal of the Academy of Marketing Science, 25, 127-137.

Reichheld, F., \& Sasser, W. Jr. (1990). Zero defections: quality comes to services. Harvard Business Review, 68(5), 105-111.

Roberts, K., Varki, S., \& Brodie, R. (2003). Measuring the quality of relationships in consumer services: an empirical study. European Journal of Marketing, 37(1/2), 169-196. http://dx.doi.org/10.1108/03090560310454037

Rusbult, C. E. (1983). A longitudinal Test of the Investment Model: The Development of satisfaction and commitment in Heterosexual Involvement. Journal of Personality and Social Psychology, 65, 101-117. http://dx.doi.org/10.1037/0022-3514.45.1.101

Sharma, N., \& Patterson, P. (1999).The effect of communication effectiveness and service quality on relationship commitment in consumer, professional services.Journal of Services Marketing, 13(2), 151-170. http://dx.doi.org/10.1108/08876049910266059

Sheth, J. N. (1996). Relationship marketing: Frameworks and concepts. Paper presented at the Berlin 1996 Conference of Relationship Marketing, 29-31.

Sheth, J. N., \&Parvatiyar, A. (2000).Handbook of Relationship Marketing. Sage Publications, Thousand Oaks, CA.

Sin, L. Y. M., Tse, A. C. B., Yau. O. H. M., Chow, R. P. M., Lee, J. S. Y., \& Lau, L. B. Y. (2005). Relationship Marketing Orientation: Scale development and Cross-cultural Validation. Journal of Business Research, 58(2), 185-194. http://dx.doi.org/10.1016/S0148-2963(02)00493-9

Skinner, S. J., Jule, B. G., \& Scott, W. K. (1992).Cooperation in Supplier-Dealer Relations. Journal of Retailing, 68(2), 174-193.

Smith, J. B. (1998). Buyer-Seller Relationships; Similarity, Relationship Management and Quality. Psychology \& Marketing, $\quad 15(1), \quad 3-21$. http://dx.doi.org/10.1002/(SICI)1520-6793(199801)15:1\%3C3::AID-MAR2\%3E3.0.CO;2-I

Tahtinen, J., \& Vaaland, T. (2006). Business relationships facing the end: why restore them? Journal of Business \& Industrial Marketing, 21(1), 14-23. http://dx.doi.org/10.1108/08858620610643139 


\section{Copyrights}

Copyright for this article is retained by the author(s), with first publication rights granted to the journal.

This is an open-access article distributed under the terms and conditions of the Creative Commons Attribution license (http://creativecommons.org/licenses/by/3.0/). 